\title{
PENGGUNAAN KONJUNGSI KOORDINATIF \\ DALAM BERITA EDITORIAL SURAT KABAR TRIBUN JAMBI BULAN JANUARI 2019
}

\author{
Firman Tara ${ }^{1}$, Nur Adawiya $\mathbf{W M}^{2}$ \\ Program Studi Pendidikan Bahasa dan Sastra Indonesia, Fakultas Keguruan dan \\ Ilmu Pendidikan, Universitas Batanghari, \\ Jambi
}

\author{
firmantara14@gmail.com \\ wiyabee@gmail.com
}

\begin{abstract}
The purpose of this research is to describe the use of coordinating conjunction on editorial news of Tribun Jambi January 2019. This research uses qualitative descriptive method. The data is in the form of sentence which contains coordinating conjunction. The source of the data is the news text on editorial news column of Tribun Jambi newspaper January 2019. The result of the research shows that there are 5 types of conjunctions used. First, there are expressions of coordinating conjunction of addition. Second, there are 3 expressions of coordinating conjunction of sequence. Third, there are 12 expressions of coordinating conjunction of contrast. Forth, there are 11 expressions of coordinating conjunction of choice. Fifth, there are 2 expressions of coordinating conjunction of explanation. Meanwhile there are two types of conjunction which are not found in the newspaper column; affirmation and compound conjunction.
\end{abstract}

Keywords: Coordinating Conjunction, Tribun Jambi Newspaper

\footnotetext{
${ }^{1}$ Dosen Program Studi Pendidikan Bahasa dan Sastra Indonesia, Fakultas Keguruan dan Ilmu Pendidikan, Universitas Batanghari, Jambi

${ }^{2}$ Mahasiswa Program Studi Pendidikan Bahasa dan Sastra Indonesia, Fakultas Keguruan dan Ilmu Pendidikan, Universitas Batanghari, Jambi
} 


\section{PENDAHULUAN}

Bahasa merupakan alat komunikasi terpenting dalam kehidupan manusia. Dalam menjalani kehidupan di dunia manusia memilih bahasa sebagai sarana untuk berkomunikasi. Dengan menggunakan bahasa sebagai sarana komunikasi, manusia akan mudah untuk menuangkan perasaan dan pikirannya pada individu lainnya. Rofii dan Hasibuan (2019) mengatakan "Fungsi bahasa yang paling mendasar ialah sebagai alat komunikasi. Bahasa digunakan masyarakat sebagai alat pergaulan antarsesama dan alat untuk menyampaikan sebuah pikiran". Menurut Pernando dan Rahima (2017:1) bahasa merupakan sarana komunikasi yang paling efektif, efisien dan praktis untuk menyampaikan pikiran dan perasaan kepada orang lain. Oleh karena itu, pemanfaatan potensi bahasa sebagai alat komunikasi dapat dilihat dalam berbagai kegiatan kehidupan bermasyarakat termasuk pengunaannya pada media cetak.

Bahasa sebagai sarana komunikasi manusia dapat dibagi ke dalam dua bentuk yaitu, bahasa komunikasi dalam bentuk bahasa lisan dan komunikasi dalam bentuk bahasa tulisan. Ketika manusia ingin menyampaikan ide, gagasan bertutur seperti itu dinamakan bahasa lisan. Namun, bila pemikiran-pemikiran dalam bentuk ide, gagasan, informasi disampaikan secara tertulis maka seperti itu dinamakan dengan komunikasi dalam bentuk tulisan.

Bentuk-bentuk tulisan yang ditulis oleh manusia atau masyarakat dapat dimuat dalam berbagai media di antaranya adalah di dalam media massa. Media massa menuliskan berbagai informasi yang dapat dibaca atau dimengerti oleh masyarakat atau khalayak ramai. Media massa juga terdiri atas beberapa jenis, di antaranya adalah surat kabar.

Surat kabar merupakan salah satu media tulis yang menginformasikan berbagai jenis informasi. Di dalam surat kabar dituliskan artikel-artikel berupa: berita, sosial, berita kriminal, ada berita politik, berita ekonomi, tajuk rencana dan teks editorial. Penulisan teks editorial di dalam surat kabar tidak terlepas dari penggunaan konjungsi (kata penghubung). Penggunaan konjungsi di dalam penulisan akan mempermudah pemahaman pembaca untuk memahami maksud tulisan itu. Berikut merupakan salah satu penggunaan konjungsi dalam redaksi editorial.

"Selain menangkap kepala daerah, turut dicokok tiga orang dari unsur pemerintah dan swasta." (Tribun Jambi)

Penggunaan konjungsi dalam sebuah tulisan dapat memperjelas sebuah bacaan sehingga mempunyai arti yang jelas. Menurut Kridalaksana (dalam Junaiyah, 2010: 36) "Konjungsi merupakan kata penghubung yang berfungsi menghubungkan kata dengan kata, frasa dengan frasa, klausa dengan klausa, kalimat dengan kalimat, dan paragraf dengan paragraf (transisi)". "Konjungsi terbagi menjadi empat bagian yaitu konjungsi koordinatif, konjungsi korelatif, konjungsi subordinatif, dan konjungsi antarkalimat" (Rahardi, 2009: 14-25). Tanpa adanya konjungsi maka suatu tulisan tidak mempunyai arti yang jelas, sehingga informasi yang disampaikan kurang padu antara satu dengan yang lainnya. Ketepatan dalam menggunakan konjungsi dalam tulisan akan memudahkan orang memahami sebuah berita, termasuk berita editorial yang ada di surat kabar.

Salah satu surat kabar yang ada di Jambi adalah surat kabar Tribun Jambi. 
Tribun Jambi adalah surat kabar yang sangat laris dibeli oleh kalangan masyarakat setempat. Hal ini terlihat dari harganya yang murah dan terjangkau. Tribun Jambi juga diminati masyarakat di pelosok-pelosok daerah di Jambi. Hal ini dapat penulis lihat dari situs Tribun Jambi yang menyatakan bahwa Tribun setiap harinya mencetak atau menghabiskan beratus helai surat kabar Tribun Jambi yang setiap harinya habis dibeli oleh pencinta pembaca surat kabar. Di dalam Tribun Jambi dituliskan juga berita editorial.

Berdasarkan hal tersebut di atas, penelitian tentang penggunaan konjungsi di dalam berita editorial di Tribun Jambi pada bulan Januari 2019 dirasa sangat penting. Adapun hal tersebut disebabkan oleh hal-hal sebagai berikut:

1. konjungsi atau kata penghubung merupakan bagian terpenting dalam sebuah karya tulis;

2. konjungsi juga berfungsi untuk menghubungkan kata dengan kata sehingga menjadi kalimat yang jelas dan padu;

3. dalam sebuah tulisan, jika kurangnya keberagaman konjungsi maka akan menyebabkan kesalahpahaman dalam memahami maksud yang akan disampaikan, khususnya di dalam merangkum berita;

4. dalam sebuah tulisan, konjungsi sangat penting dan dibutuhkan, karena jika tidak, sebuah tulisan tersebut tidak memiliki arti dan tujuan yang jelas.

Berdasarkan latar belakang tersebut, persoalan yang terkait dengan konjungsi sangat luas. Konjungsi terbagi menjadi empat bagian yaitu konjungsi koordinatif, konjungsi korelatif, konjungsi subordinatif, dan konjungsi antarkalimat. Dalam penelitian ini hanya difokuskan pada konjungsi koordinatif. Konjungsi koordinatif dapat dilihat atau dianalisis dari berbagai sudut penelitian. Konjungsi koordinatif dapat diteliti dari segi bentuk, makna, ataupun fungsi konjungsi koordinati dalam teks atau tulisan.

Berdasarkan identifikasi yang cukup luas di atas maka penelitian ini berfokus pada fungsi konjungsi koordinatif sebagai penanda hubungan pada teks editorial pada surat kabar Tribun Jambi bulan Januari 2019. Adapun fungsi konjungsi koordinatif meliputi tujuh bagian, yaitu (1) penanda hubungan penjumlahan, (2) penanda hubungan penegas, (3) penanda hubungan perurutan, (4) penanda hubungan perlawanan atau pertentangan, (5) penanda hubungan pemilihan, (6) penanda hubungan perincian, dan (7) penanda hubungan kombinasi.

Berdasarkan fokus penelitian di atas maka pertanyaan penelitian dalam penelitrian ini adalah sebagai berikut.
1. Bagaimana fungsi konjungsi koordinatif sebagai penanda hubungan penjumlahan dalam berita editorial surat kabar Tribun Jambi bulan Januari 2019?

2. Bagaimana fungsi konjungsi koordinatif sebagai penanda hubungan penegas dalam berita editorial surat kabar Tribun Jambi bulan Januari 2019?

3. Bagaimana fungsi konjungsi koordinatif sebagai penanda hubungan perurutan dalam berita editorial surat kabar Tribun Jambi bulan Januari 2019?

4. Bagaimana fungsi konjungsi koordinatif sebagai penanda hubungan perlawanan atau pertentangan dalam berita editorial surat kabar Tribun Jambi bulan Januari 2019?

5. Bagaimana fungsi konjungsi koordinatif sebagai penanda hubungan pemilihan dalam berita 
editorial surat kabar Tribun Jambi bulan Januari 2019?

6. Bagaimana fungsi konjungsi koordinatif sebagai penanda hubungan perincian dalam berita editorial surat kabar Tribun Jambi bulan Januari 2019?

7. Bagaimana fngsi konjungsi koordinatif sebagai penanda hubungan kombinasi dalam berita editorial surat kabar Tribun Jambi bulan Januari 2019?

Berdasarkan fokus penelitian dan pertanyaan penelitian yang telah diuraikan, maka tujuan dari penelitian ini sebagai berikut.

1. Mendeskripsikan bagaimana fungsi konjungsi koordinatif sebagai penanda hubungan penjumlahan dalam berita editorial surat kabar Tribun Jambi bulan Januari 2019.

2. Mendeskripsikan bagaimana fungsi konjungsi koordinatif sebagai penanda hubungan penegas dalam berita editorial surat kabar Tribun Jambi bulan Januari 2019.

3. Mendeskripsikan bagaimana fungsi konjungsi koordinatif sebagai penanda hubungan perurutan dalam berita editorial surat kabar Tribun Jambi bulan Januari 2019.

4. Mendeskripsikan bagaimana fungsi konjungsi koordinatif sebagai penanda hubungan perlawanan atau pertentangan dalam berita editorial surat kabar Tribun Jambi bulan Januari 2019.

5. Mendeskripsikan bagaimana fungsi konjungsi koordinatif sebagai penanda hubungan pemilihan dalam berita editorial surat kabar Tribun Jambi bulan Januari 2019.

6. Mendeskripsikan bagaimana fungsi konjungsi koordinatif sebagai penanda hubungan perincian dalam berita editorial surat kabar Tribun Jambi bulan Januari 2019.
7. Mendeskripsikan bagaimana fungsi konjungsi koordinatif sebagai penanda hubungan kombinasi dalam berita editorial surat kabar Tribun Jambi bulan Januari 2019.

Adapun beberapa manfaat yang diperoleh dari penelitian sebagai berikut. Secara teoretis, hasil penelitian ini diharapkan akan memberikan manfaat menambah ilmu pengetahuan dan menambah teori-teori. Tentunya, manfaat tersebut dapat dirasakan apa bila pengetahuan dan teori-teori yang dicari berkaitan dengan penggunaan konjungsi koordinatif pada berita editorial surat kabar Tribun Jambi.

Secara praktis, hasil penelititian ini dapat bermanfaat untuk berbagai pihak, sebagai berikut.

1. Bagi masyarakat umum diharapkan dapat digunakan sebagai acuan dalam memahami berita editorial Tribun Jambi.

2. Bagi penulis dapat menambah wawasan, sehingga lebih memahami penggunaan konjungsi koordinatif dalam editorial surat kabar.

3. Bagi peneliti selanjutnya diharapkan dapat digunakan sebagai bahan acuan untuk penelitian selanjutnya, yang berhubungan dengan penggunaan konjungsi koordinatif dalam editorial.

\section{METODE PENELITIAN}

Jenis penelitian ini adalah penelitian kualitatif. Metode yang digunakan dalam penelitian ini yaitu metode deskriptif. Menutut Djajasudarma (2010:9) "Metode deskriptif adalah metode yang bertujuan membuat deskripsi maksudnya membuat gambaran, lukisan secara sistematis, factual, dan akurat mengenai data, sifatsifat serta hubungan fenomena-fenomena yang diteliti."

Penelitian kualitatif ditekankan pada deskripsi. "Penelitian kualitatif 
ditekankan pada deskripsi objek yang diteliti” (Berg dalam Muhammad, 2011:30). "Penelitian kualitatif dilakukan dengan tidak mengutamakan pada angkaangka, tetapi mengutamakan kedalam penghayalan terhadap interaksi antar konsep yang sedang dikaji secara empiris" (Semi, 2012:28). Penelitian deskriptif kualitatif adalah penelitian yang berfungsi untuk menyederhanakan serta memecahkan masalah yang ada secara apa adanya dengan data yang empiris.

"Data adalah informasi atau keterangan baik kualitatif yang menunjukkan fakta" (Sedarmayanti dan Hidayat, 2011:72). Data dalam penelitian yaitu kalimat yang mengandung konjungsi koordinatif yang terdapat dalam berita editorial pada surat kabar Tribun Jambi edisi Januari 2019. Sumber data adalah subjek darimana dapat diperoleh (Arikunto, 2010:172). Sumber data dalam penelitian ini yaitu berupa surat kabar Tribun Jambi berupa berita editorial.

Menurut Sugiyono (2013:224)

"Teknik pengumpulan data merupakan langkah yang paling strategis dalam penelitian, karena tujuan utama dari penelitian adalah mendapatkan data."

Adapun langkah-langkah dalam mengumpulkan data dalam penelitian ini adalah sebagai berikut:

1. Studi pustaka. Teknik ini digunakan untuk mencari buku-buku atau teoriteori mengenai fungsi konjungsi koordinatif, berita editorial, ataupun literatur lain yang erat kaitannya dengan penelitian ini.

2. Dokumentasi digunakan untuk mengumpulkan data-data penelitian pada berita editorial dalam surat kabar Tribun Jambi edisi Januari 2019.

3. Setelah data terkumpul, peneliti kemudian mengklasifikasikan data sesuai dengan fungsi konjungsi koordinatif yang meliputi 7 penanda, yaitu (1) penanda hubungan penjumlahan, (2) penanda hubungan penegas, (3) penanda hubungan perurutan, (4) penanda hubungan perlawanan atau pertentangan, (5) penanda hubungan pemilihan, (6) penanda hubungan perincian, dan (7) penanda hubungan kombinasi.

Menurut Sugiyono (2013:244) "Analisis data adalah proses mencari dan menyusun secara sistematis data yang diperoleh dari hasil wawancara, catatan lapangan dan dokumentasi dengan cara mengorganisasikan data ke dalam kategori, menjabarkan ke dalam unitunit, melakukan sintesa, menyusun ke dalam pola, memilih mana yang penting dan yang akan dipelajari dan membuat kesimpulan sehingga mudah dipahami oleh diri sendiri maupun orang lain."

Analisis data dalam penelitian ini bersifat deskriptif kualitatif. Hal ini dikarenakan objek yang diteliti berupa data-data yang memerlukan penjelasan secara deskriptif. Adapun kegiatan menganalisis data dalam penelitian ini seperti yang diungkapkan oleh Miles and Huberman dalam Sugiyono (2013:246), sebagai berikut.

\section{Reduksi Data}

Langkah awal yang dilakukan adalah melakukan reduksi data. Dalam mereduksi data, penulis berpijak pada sebuah tujuan. Berita yang ada di surat kabar Tribun Jambi tersebut, diberikan kode pada masing-masing berita. Pengkodean ini diberikan agar dalam menganalisis masing-masing berita tersebut akan lebih mudah. Karena berita editorial pada surat kabar ini hampir setiap harinya dimuat. Untuk lebih mudah lagi, penulis mencantumkan data-data yang didapat ke dalam tabel.

2. Penyajian Data 
Setelah data direduksi. Langkah selanjutnya yaitu penyajian data yang dilakukan dalam bentuk uraian singkat. Artinya data yang telah direduksi dalam tabel, kemudian dideskripsikan secara jelas supaya dapat dimengerti orang lain.

3. Triangulasi data. Dalam hal ini mengeni keabsahan data penulis berkonsultasi dengan pembimbing, teman-teman yang telah selesai studi, serta teman-teman yang sedang menyelesaikan skripsi.

4. Penarikan Kesimpulan

Langkah selanjutnya yaitu penarikan kesimpulan dengan tujuan menjawab pertanyaan penelitian yang telah dirumuskan di awal.

\section{HASIL DAN PEMBAHASAN}

Pada bagian ini disajikan hasil penelitian fungsi konjungsi koordinatif yang terdapat pada teks editorial pada surat kabar Tribun Jambi bulan Januari 2019. Dari jumlah terbitan surat kabar Tribun pada bulan Januari yang berjumlah 31, ditemukan 17 editorial yang digunakan sebagai data penelitian. Berdasarkan hasil analisis data yang telah dilakukan, ditemukan fungsi konjungsi koordinatif yang terdapat pada teks editorial pada surat kabar Tribun Jambi bulan Januari 2019 sebanyak 47 kutipan, dengan rincian sebagai berikut.

1. Fungsi konjungsi koordinatif sebagai penanda hubungan penjumlahan dalam berita editorial surat kabar Tribun Jambi bulan Januari 2019 ditemukan 19 kutipan.

2. Fungsi konjungsi koordinatif sebagai penanda hubungan penegas dalam berita editorial surat kabar Tribun Jambi bulan Januari 2019 ditemukan 0 kutipan.

3. Fungsi konjungsi koordinatif sebagai penanda hubungan perurutan dalam berita editorial surat kabar Tribun
Jambi bulan Januari 2019 ditemukan 3 kutipan.

4. Fungsi konjungsi koordinatif sebagai penanda hubungan perlawanan atau pertentangan dalam berita editorial surat kabar Tribun Jambi bulan Januari 2019 ditemukan 12 kutipan.

5. Fungsi konjungsi koordinatif sebagai penanda hubungan pemilihan dalam berita editorial surat kabar Tribun Jambi bulan Januari 2019 ditemukan 11 kutipan.

6. Fungsi konjungsi koordinatif sebagai penanda hubungan perincian dalam berita editorial surat kabar Tribun Jambi bulan Januari 2019 ditemukan 2 kutipan.

7. Fungsi konjungsi koordinatif sebagai penanda hubungan kombinasi dalam berita editorial surat kabar Tribun Jambi bulan Januari 2019 ditemukan 0 kutipan.

\section{Fungsi Konjungsi Koordinatif sebagai Penanda Hubungan Penjumlahan dalam Berita Editorial Surat Kabar Tribun Jambi Bulan Januari 2019}

\section{Kutipan 1 \\ Transaksi tak memerlukan tempat khusus. Cukup dengan media sosial. Dalam kasus ini adalah istagram, para pelaku prostitusi dan calon pelanggan, dengan perantara mucikari, membuat janji, uang transfer, lalu terjadilah pertemuan. (ED-08)}

Pada kutipan (1) di atas, diketahui bahwa berdasarkan makna penjumlahan, fungsi konjungsi koordinatif dan pada kutipan di atas menghubungkan dua konstituen antara para pelaku prostitusi dan calon pelanggan. Keuda konstituen tersebut yang memiliki kedudukan setara, dengan tujuan menyatakan dan menandai pertalian semantik penjumlahan, sedangkan konjungsi koordinatif dengan 
menghubungkan dua konstituen antara para pelaku prostitusi dan calon pelanggan serta perantara mucikari yang juga yang memiliki kedudukan setara, dengan tujuan menandai pertalian semantik penjumlahan.

Kutipan 2

Di zaman di mana konsumerisme semakin merasuk dalam sendi-sendi kehidupan, pendidikan moral dan agama menjadi semakin penting. Dengan memasukkan standar moral yang baik, pendidikan agama yang kontinu menjadi benteng awal dan terakhir bagi manusia. (ED-08)

Pada kutipan (2) di atas, diketahui bahwa berdasarkan makna penjumlahan, fungsi konjungsi koordinatif dan yaitu menghubungkan dua konstituen antara pendidikan moral dan agama, yang memiliki kedudukan setara, dengan tujuan menyatakan dan menandai pertalian semantik penjumlahan; sedangkan konjungsi koordinatif dan yang kedua menghubungkan dua konstituen antara benteng awal dan terakhir yang juga memiliki kedudukan setara menyatakan dan menandai pertalian semantik penjumlahan.

\section{Fungsi Konjungsi Koordinatif sebagai Penanda Hubungan Penegas dalam Berita Editorial Surat Kabar Tribun Jambi Bulan Januari 2019}

Pada berita editorial surat kabar Tribun Jambi bulan Januari 2019 tidak ditemukan kutipan konjungsi koordinatif sebagai hubungan penanda penegas.

\section{Fungsi Konjungsi Koordinatif sebagai Penanda Hubungan Perurutan dalam Berita Editorial Surat Kabar Tribun Jambi Bulan Januari 2019}

Kutipan 1

Transaksi tak memerlukan tempat khusus. Cukup dengan media sosial. Dalam kasus ini adalah istagram, para pelaku prostitusi dan calon pelanggan, dengan perantara mucikari, membuat janji, uang transfer, lalu terjadilah pertemuan. (ED-08)

Pada kutipan (1) di atas, diketahui bahwa berdasarkan berdasarkan makna perurutan yaitu kata hubung lalu yang menghubungkan dua konstituen atau lebih antara Dalam kasus ini adalah istagram, para pelaku prostitusi dan calon pelanggan, dengan perantara mucikari, membuat janji, uang transfer dan terjadilah pertemuan yang memiliki kedudukan setara dengan tujuan menyatakan perbuatan atau peristiwa yang yang berulang-ulang.

Kutipan 2

Pertama, pejabat korup tertangkap KPK, disidangkan di pengadilan, lalu dijatuhi hukuman sekitar 2 sampai 4 tahun, ternyata. (ED-25)

Pada kutipan (2) di atas, berdasarkan berdasarkan makna perurutan yaitu kata hubung lalu yang menghubungkan dua konstituen atau lebih antara pejabat korup tertangkap $K P K$, disidangkan di pengadilan dan dijatuhi hukuman sekitar 2 sampai 4 tahun yang memiliki kedudukan setara dengan tujuan menyatakan perbuatan atau peristiwa yang yang berulang-ulang.

\section{Fungsi Konjungsi Koordinatif sebagai Penanda Hubungan Perlawanan Atau Pertentangan dalam Berita Editorial Surat Kabar Tribun Jambi Bulan Januari 2019}

Kutipan 1

Semestinya perhelatan Porprov itu di Kabupaten Merangin November lalu, 
namun mereka tidak siap dengan alasan bersamaan dengan pesta demokrasi pemilihan kepala daerah (Pilkada). (ED10)

Pada kutipan (1) di atas, diketahui berdasarkan penanda hubungan perlawanan yaitu kata hubung namun yang menghubungkan dua konstituen atau lebih antara perhelatan Porprov itu di Kabupaten Merangin November lalu dan mereka tidak siap dengan alasan bersamaan dengan pesta demokrasi yang memiliki kedudukan setara dengan tujuan menyatakan bahwa apa yang dinyatakan pada klausa yang satu berlawanan atau sekalipun tidak berlawanan, tetapi dipertentangkan dengan apa yang dinyatakan pada klausa lainnya.

Kutipan 2

Maka dialihkan ke Bungo-Tebo, tapi lagi-lagi tak siap, dan akhirnya KONI Provinsi yang menanggung beban ini. (ED-10)

Pada kutipan (2) di atas, diketahui berdasarkan penanda hubungan perlawanan yaitu kata hubung tapi yang menghubungkan dua konstituen atau lebih antara Maka dialihkan ke BungoTebo dan lagi-lagi tak siap, yang memiliki kedudukan setara dengan tujuan memberi makna pertentangan atau perlawanan pada maksud isi kalimat serta menyatakan bahwa apa yang dinyatakan pada klausa yang satu berlawanan atau sekalipun tidak berlawanan, tetapi dipertentangkan dengan apa yang dinyatakan pada klausa lainnya.

\section{Fungsi Konjungsi Koordinatif sebagai Penanda Hubungan Pemilihan dalam Berita Editorial Surat Kabar Tribun Jambi Bulan Januari 2019}

Kutipan 1
Kalau dahulu praktik semacam ini lebih sering memicu rasa kepedulian karena pelakunya yang mengalami paksaan, atau karena alasan kemiskinan, kini sudah semakin terbuka, praktik ini digeluti juga oleh mereka yang berpunya. (ED-08)

Pada kutipan (1) di atas, diketahui fungsi konjungsi koordinatif berdasarkan makan pemilihan yaitu kata hubung atau yang menghubungkan dua konstituen atau lebih antara karena pelakunya yang mengalami paksaan dan karena alasan kemiskinan yang keduanya memiliki kedudukan sama, dengan tujuan memberi makna pemilihan.

Kutipan 2

Mungkin saja, ditunjuknya Kabupaten Merangin adalah "hadiah" atau konpensasi atas kegagalan pelaksanaan Pekan Olahraga Provinsi (Porprov). (ED-10)

Pada kutipan 2 di atas, fungsi konjungsi koordinatif berdasarkan makna pemilihan yaitu kata hubung atau yang menghubungkan dua konstituen atau lebih antara Kabupaten Merangin adalah "hadiah" dan konpensasi atas kegagalan pelaksanaan Pekan Olahraga Provinsi yang memiliki kedudukan sama, dengan tujuan memberi makna pemilihan.

\section{Fungsi Konjungsi Koordinatif sebagai Penanda Hubungan Perincian dalam Berita Editorial Surat Kabar Tribun Jambi Bulan Januari 2019}

Kutipan 1
Pemerintah maupun pihak masyarakat
yang dipresentasikan oleh inaca
menyebut bahwa kenaikan harga itu
tidak melebihi tarif. (ED-14)
$\quad$ Pada kutipan (1) di atas, diketahui
penanda hubungan perincian atau
penjelasan bahwa merupakan konjungsi 
yang berfungsi untung menghubungkan dua konstituen antara pihak masyarakat yang dipresentasikan oleh inaca dan kenaikan harga itu tidak melebihi tarif yang memiliki kedudukan yang sama, dengan tujuan memberi makna penjelasan di mana klausa kedua berlaku sebagai penjelas dari keadaan, peristiwa, atau hal pada klausa pertama

Kutipan 2

Masalah ini juga terjadi di Kota Jambi, bahkan tahun ini sebaran DBD di tanah pilih Pseko Betuah jauh lebih tinggi dibanding tahun lalu. (ED-31)

Pada kutipan (2) di atas, diketahui penanda hubungan perincian atau penjelasan bahkan merupakan konjungsi yang berfungsi untung menghubungkan dua konstituen antara Masalah ini juga terjadi di Kota Jambi dan tahun ini sebaran DBD di tanah pilih Pseko Betuah jauh lebih tinggi dibanding tahun lalu yang memiliki kedudukan yang sama, dengan tujuan memberi makna penjelasan di mana klausa kedua berlaku sebagai penjelas dari keadaan, peristiwa, atau hal pada klausa pertama.

\section{Fungsi Konjungsi Koordinatif sebagai Penanda Hubungan Kombinasi dalam Berita Editorial Surat Kabar Tribun Jambi Bulan Januari 2019}

Pada berita editorial surat kabar Tribun Jambi bulan Januari 2019 tidak ditemukan kutipan penggunan konjungsi koordinatif sebagai hubungan penanda hubungan kombinasi.

\section{SIMPULAN}

Berdasarkan hasil penelitian dan pembahasan yang telah dijabarkan, dapat ditarik kesimpulan bahwa terdapat lima aspek fungsi konjungsi koordinatif di dalam berita editorial surat kabar Tribun
Jambi bulan Januari 2019 yaitu: (1) fungsi konjungsi koordinatif penanda hubungan penjumlahan ditemukan sebanyak 19 kutipan; (2) fungsi konjungsi koordinatif penanda hubungan perurutan ditemukan sebanyak 3 kutipan; (3) fungsi konjungsi koordinatif penanda hubungan perlawanan ditemukan sebanyak 12 kutipan; (4) fungsi konjungsi koordinatif penanda hubungan pemilihan ditemukan sebanyak 11 kutipan; (5) fungsi konjungsi koordinatif penanda hubungan perincian ditemukan sebanyak 2 kutipan; sedangkan fungsi konjungsi koordinatif penanda hubungan penegas dan fungsi konjungsi koordinatif penanda hubungan kombinas tidak ditemukan. Berikut simpulan dari kelima aspek tersebut.

\section{SARAN}

Sebuah karya tulis tentunya menginginkan suatu hal yang bermanfaat. Melalui penelitian ini, penulis ingin menyampaikan saran dari hasil penelitian pada penggunaan konjungsi koordinatif dalam berita editorial surat kabar Tribun Jambi bulan Januari 2019 sebagai berikut:

1. Bagi penulis berita atau jurnalis agar mampu menggunakan konjungsi khususnya konjungsi koordinarif secara tepat sehingga berita dapat dengan mudah dipahami oleh pembaca.

2. Bagi mahasiswa khususnya mahasiswa program studi pendidikan bahasa dan sastra Indonesia, hendaknya lebih meningkatkan pengetahuan mengenai konjungsi beserta macam-macamnya, karena mempunyai kegunaan masing-masing yang mungkin tidak diketahui sebelumnya. Agar nantinya pada saat menulis tidak salah menempatkan sebuah kata penghubung. 
3. Bagi peneliti-peneliti selanjutnya, hendaknya dapat menjadi ilmu pengetahuan baru dan dapat menjadi acuan jika ingin mengkaji serta melanjutkan penelitian tentang konjungsi khususnya konjungsi koordinatif.

\section{DAFTAR PUSTAKA}

Arikunto, Suharsimi. (2010). Prosedur Penelitian. Suatu Pendekatan Praktik. Jakarta: Rineka Cipta.

Djajasudarma, Fatimah. (2010). Metode Linguistik Ancangan Metode Penelitian dan Kajian. Bandung: Refika Aditama.

Muhammad. (2011). Metode Penelitian Bahasa. Yogyakarta: Ar-Ruzz Media.

Pernando, E., \& Rahima, A. (2017). Analisis Kohesi Leksikal dalam Majalah Patriotik LPM Universitas Batanghari Edisi XVI Juli-September Tahun 2016. Aksara: Jurnal Ilmiah Pendidikan Bahasa dan Sastra Indonesia, 1(1), 1-10.

Rahardi, Kunjana. (2009). Penyuntingan Bahasa Indonesia untuk Karang Mengarang. Yogyakarta: Erlangga.

Rofii, Afif. dan Hasibuan, Rizka Rani. (2019). Interferensi Bahasa Batak Mandailing dalam Tuturan Berbahasa Indonesia Pada Acara Parpunguan Masyarakat Mandailing Kota Jambi. Aksara: Jurnal Ilmiah Pendidikan Bahasa dan Sastra Indonesia Vol. 3 No. $1 \quad$ April 2019 aksara.unbari.ac.id/index.php/aks ara/article/download/94/50.

Semi, M. Atar. (2012). Metode Penelitian Sastra. Bandung: CV Angkasa.

Sugiyono. (2013). Metode Penelitian Pendidikan Pendekatan
Kualitatif, Kuantitatif, dan $R \& D$. Bandung: Alfabeta.

Kurang daftar Pustaka

(Junaiyah, 2010: 36)

(Sedarmayanti dan Hidayat, 2011:72). 